\title{
Article \\ Contemporary Sound Practices: Church Bells and Bell Ringing in New South Wales, Australia
}

\author{
Murray Parker (D) and Dirk H. R. Spennemann *(D) \\ Institute for Land, Water and Society, Charles Sturt University, P.O. Box 789, Albury, NSW 2640, Australia; \\ muparker@csu.edu.au \\ * Correspondence: dspennemann@csu.edu.au
}

check for updates

Citation: Parker, M.; Spennemann, D.H.R. Contemporary Sound Practices: Church Bells and Bell Ringing in New South Wales, Australia. Heritage 2021, 4, 1754-1772. https://doi.org/10.3390/heritage 4030098

Academic Editor: Nicola Masini

Received: 1 July 2021

Accepted: 9 August 2021

Published: 12 August 2021

Publisher's Note: MDPI stays neutral with regard to jurisdictional claims in published maps and institutional affiliations.

Copyright: (c) 2021 by the authors. Licensee MDPI, Basel, Switzerland. This article is an open access article distributed under the terms and conditions of the Creative Commons Attribution (CC BY) license (https:// creativecommons.org/licenses/by/ $4.0 /)$.

\begin{abstract}
As a social species, humans have developed soundscapes that surround, and to some extent circumscribe, their daily existence. The concept of aural heritage, its conceptualization and its management represent a rapidly expanding area of research, covering aspects of both natural and human heritage. However, there have been no contemporary regional or supra-regional studies that examine the nature of sound making in Christian religious settings, nor the extent to which it is still used. This paper presents the results of a survey into the presence of bells and bell ringing practices among five major Christian denominations in New South Wales, and examines to what extent bell ringing is still practiced and what factors may determine any differentiation. In doing so, it provides an objective basis from which to investigate future changes in bell ringing practices, and provides a solid foundation with reference to aural heritage of sound in a religious setting.
\end{abstract}

Keywords: cultural heritage; audio heritage; soundscapes; aural heritage; church bells

\section{Introduction}

As a social species cohabiting in colonies of varied sizes (villages, towns, cities), humans have developed soundscapes that surround, and to some extent circumscribe, their daily existence. These soundscape components may be ancillary, i.e., emanating from activities conducted by people (e.g., factory sounds, sounds emerging from traffic), or intentional, i.e., emanating from sound making devices designed to notify the public of events or dangers (e.g., bells rung in a church, loudspeaker announcements at subway train stations). These soundscapes are not static but undergo changes concurrent with changes in the patterns of the underlying human activity, as a soundscape is the perception of an acoustic environment in a contextual setting [1].

Depending on how these soundscapes are perceived, they are regarded as negative ('noise') or positive, in which case they may be deemed worth keeping/preserving and may be conceptualized as 'heritage'. The documentation and preservation of traces of past human endeavor and behavior is the realm of cultural heritage management, which has developed an array of criteria and protocols for the identification and management of humanity's heritage. Most of these activities are focused on tangible expressions of heritage, such as objects, structures and places [2-4]. There is a growing body of research, including international conventions, that addresses the identification and management of intangible cultural heritage, which is too extensive to be reviewed here [5-7].

The concept of aural heritage, its conceptualization and its management represent a rapidly expanding area of research, covering aspects of both natural and human heritage. Previous work, for example, has attributed value to sounds in natural heritage spaces, such as avian soundscapes [8], soundscapes in cities and neighborhoods [9], and sounds in specific, spatially defined areas $[10,11]$. As with all constructs of value, the perception and conceptualization of soundscapes in natural spaces is anthropogenic [12], even though extraneous sounds may not only collide with the human perception of 'nature' but also interfere with inter- and intra-species faunal communication [13]. 
Being publicly available, soundscapes have multiple receivers and demonstrate a high difficulty of exclusion from the public [14]. Much work has shown that there are positive effects on mood and perceived quality of life and wellbeing when participants are presented with sounds of nature [15], to the extent that natural soundscapes are increasingly being designed for the built environment $[15,16]$.

A number of studies have considered the internal acoustic properties of religious structures from a technical and workplace safety aspect [17-19], as well as in terms of their cultural heritage dimensions [20-23]; the effects of bell ringing on ground motion [24]; the soundscapes associated with places of worship [25-29]; people's perceptions of evening bell ringing with reference to impression and loudness [30,31]; and people's preferences in bell ringing in terms of congruence of the soundscape [32].

All of these studies, however, are focused on single properties or localities. There are, to date, no contemporary regional or supra-regional studies that examine the nature of sound making in Christian religious settings, nor the extent to which it is still used.

This paper presents the results of a survey into the presence of bells in churches of five major Christian denominations in New South Wales and examines to what extent bell ringing is still practiced on the church premises.

\section{Methods}

A quantitative survey was designed with open-ended qualitative questions to investigate the use of, and values attributed to bells and bell ringing on church premises in the state of New South Wales (NSW), Australia. This study area was selected as this state is Australia's most populous state, has a comparable denominational breakdown to the rest of the country, and has a relatively uniform representation of Remoteness Areas (Figure 1). The structure, design and procedures of the survey followed standard methodology, as set out in Bickman and Rog [33], Dillman et al. [34] and Sarantakos [35], and definitions and conceptual frameworks pertaining to the concept of soundscapes were guided by ISO 12913-1 [1]. Quantitative questions solicited information concerning history of the church; number, specifications and types of bells on-site; and ringing patterns for these bells. For the purposes of this manuscript, freeform comments pertained to simple matters such as "To which location were these bells removed?" and "Is there anything you would like to add about the history of tower bells on your church premises?". Other freeform comments investigated values, perceptions and attitudes of the respondents, but as these data are reported elsewhere [36], we have not included these questions here. See Figure 2 for a flowchart summary of methodological processes.

\subsection{Identification of Sampling Frame and Recruitment}

It is acknowledged that bells may be rung in both Buddhist and Hindu temples and that the Azan call to prayer may be broadcast at Islamic mosques. For the purposes of this study, only Christian denominations were included so that the data collected may be easily comparable between churches of different denominations due to the potential similarity of Christian church service procedures. According to the 2016 census of Australia [37], the top five denominations of Christian faith are Roman Catholic (ROC, 37.64\%), Anglican (ANG, 23.68\%), Uniting Church (UNI, 4.43\%), Eastern Orthodox Church (ORT, 3.84\%) and Presbyterian and Reformed (PRE, 3.84\%).

Contact details of all churches within these denominations in NSW were collected from publicly available sources, primarily online diocese/parish and clergy listings. Primary contact and an invitation to participate in the survey was made via e-mail, or where this could not be sourced, via post as identified through the online church listings or found manually through the Google search engine [34].

\subsection{Implementation}

Two identical versions of the survey were developed: an online version administered via SurveyMonkey, and a paper-based version which required manual data entry of the 
returns [38]. To reduce the number of survey questions and to facilitate a structured data collection process, five separate SurveyMonkey links were generated (one per denomination) and emailed to potential participants (1125 invitations). Similarly, five versions of the paper survey were posted, with the denomination named in the document footer (264 invitations).

If an identified email contact address was rejected by a mail server, the church was then contacted by post. For the 12 posted surveys that were received back marked 'return to sender', no further contact with the church office was attempted. In total, 1389 survey forms were administered on 25/26 November 2017 with two follow-ups in subsequent weeks. The survey was closed on 19 February 2018 (online) and on 10 April 2018 (paper) due to a very clearly observed trail in responses [33]. No surveys were accepted after these dates. The total response rate for the survey was $40.1 \%$, with a higher response rate for both Anglican and Uniting Church denominations (56.1\% and $41 \%$ respectively) and a low response rate for Eastern Orthodox churches (12.8\%) (Table 1). Although recruitment was very high for the Anglican and Uniting denominations, and high for Catholic and Presbyterian churches (around 30\% each), the low number of returns for Orthodox churches $(n=11)$ makes it difficult to extrapolate data for that denomination.

Table 1. Details of surveys sent out and returned.

\begin{tabular}{|c|c|c|c|c|c|c|c|}
\hline \multirow{2}{*}{ - } & \multicolumn{3}{|c|}{ Electronic Surveys } & \multicolumn{2}{|c|}{ Paper } & \multirow{2}{*}{ Valid Returns } & \multirow{2}{*}{ Response Rate (\%) } \\
\hline & Invited & Started & Stopped & Sent Out & Returned & & \\
\hline Anglican & 409 & 257 & 10 & 60 & 25 & 263 & 56.1 \\
\hline Catholic & 303 & 100 & 4 & 40 & 12 & 104 & 30.3 \\
\hline Uniting & 226 & 111 & 5 & 84 & 24 & 127 & 41.0 \\
\hline Presbyterian & 123 & 39 & - & 58 & 15 & 52 & 28.7 \\
\hline Orthodox & 64 & 10 & - & 22 & 1 & 11 & 12.8 \\
\hline Total & 1125 & 517 & 19 & 264 & 77 & 557 & 40.1 \\
\hline
\end{tabular}

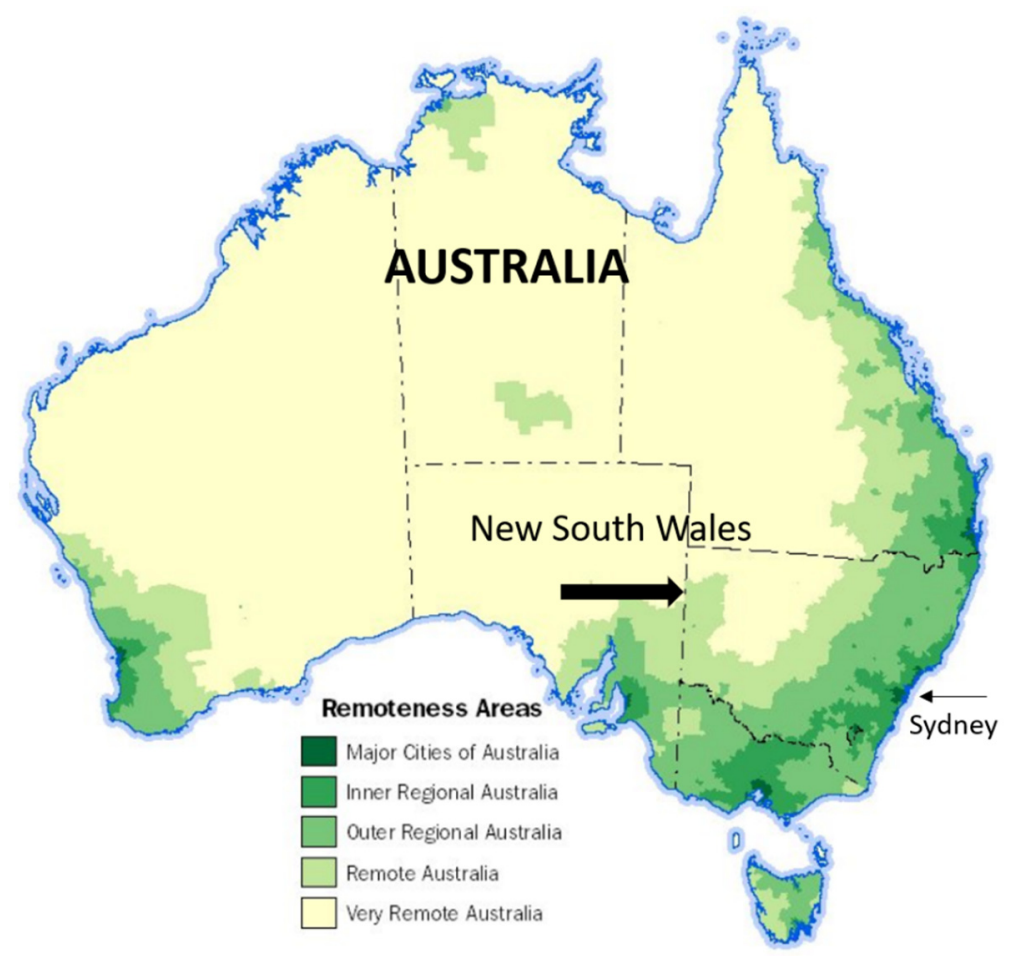

Figure 1. Map of Australia, showing the study area of New South Wales and levels of remoteness (source: https:/ /www. abs.gov.au/websitedbs/D3310114.nsf/home/remoteness+structure (accessed on 1 August 2021)). 


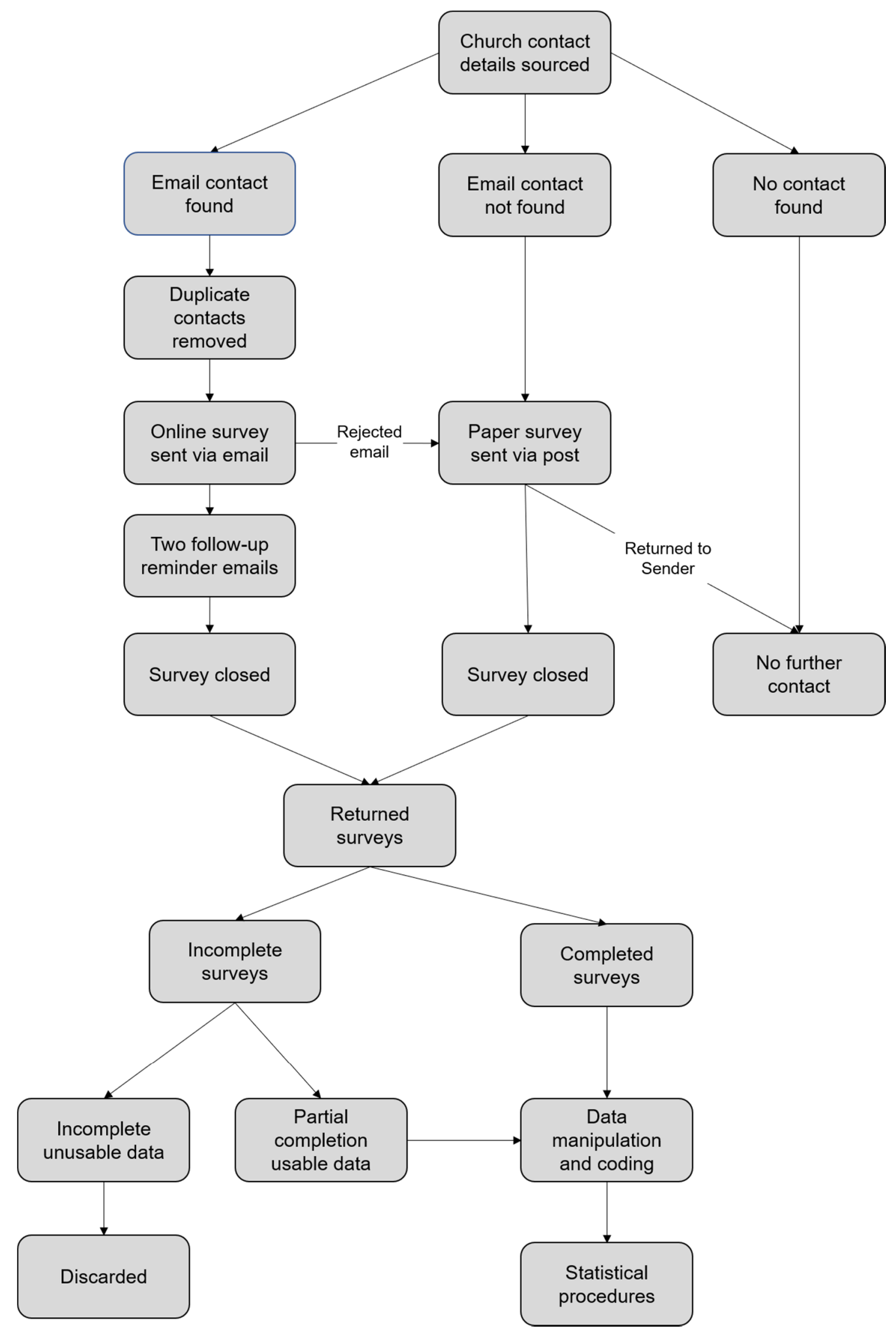

Figure 2. Flowchart outlining the methodological processes of data collection, manipulation and coding, and statistical procedures. 


\subsection{Data Manipulation and Coding}

The category of 'campanile', defined as an 'outdoor freestanding bell tower, removed from the actual body of a church', was generated from the data. This was necessary due to the large number of participants who reported the presence of a bell (often rung) that did not seem to constitute a traditional tower bell (Figures 3 and 4). Such inclusions $(n=25)$ were 'bell hanging on detached gantry, i.e., completely separate structure from church', 'single external bell', 'bell mounted on post' and 'free standing outdoor bell'. Other bells $(n=7)$, which were identified as being located on the roof, in a bell-côte or in a belfry, were recoded as a 'tower bell' as they were physically attached to the body of the church.

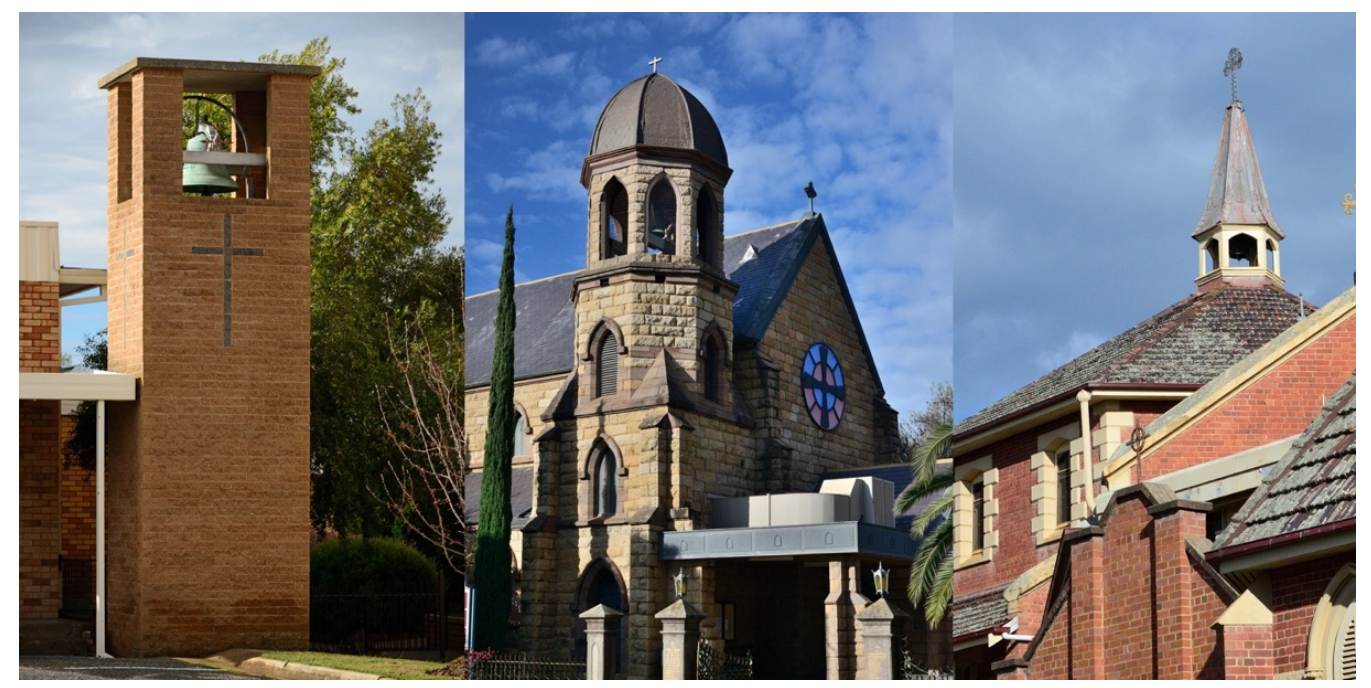

Figure 3. Types of bell mounts used in churches in NSW. From left: campanile, Sacred Heart Catholic Church; bell tower, St. Patrick's Catholic Church; bell-côte, St. Ursula's Catholic Convent (all Albury) (photos: Dirk HR Spennemann).

Based on the postcode, all responses were classified into regionality categories as defined by the Australian Bureau of Statistics [39]: major cities of Australia (i.e., Greater Sydney in the NSW scenario), inner regional NSW, outer regional NSW, remote NSW and very remote NSW.

The actual 'bell ringing days' of each church were determined by attributing estimated yearly bell ringing days to each response category (never $=0$, less than once a year $=0.5$, once a year $=1$, less than once a month but more than once a year $=3$, less than once a month $=6$, once a month $=12$, once a fortnight $=26$, once a week $=52$, and two or more times per week $=104$ days).

\subsection{Statistical Analysis}

The data were analyzed descriptively: comparisons were made between respondents from differing denominations, regionalities and roles within the church, as well as grouped by respondents that had or did not have bells on the church premises. Quantitative data were analyzed using Statistical Package for the Social Sciences (IBM SPSS Statistics 24). Data were checked for normality prior to analysis. Continuous data were initially explored using the Pearson correlation coefficient; unpaired $t$-tests were used to compare responses between groups (e.g., churches with/without bells); one-way analysis of variance (ANOVA) was used when there were three or more groups (e.g., comparing between denominations or roles within the church); and categorical variables were compared using the Chi-square test. Statistical significance was set at $p<0.05$; values are reported as proportions, and mean \pm standard deviation. 


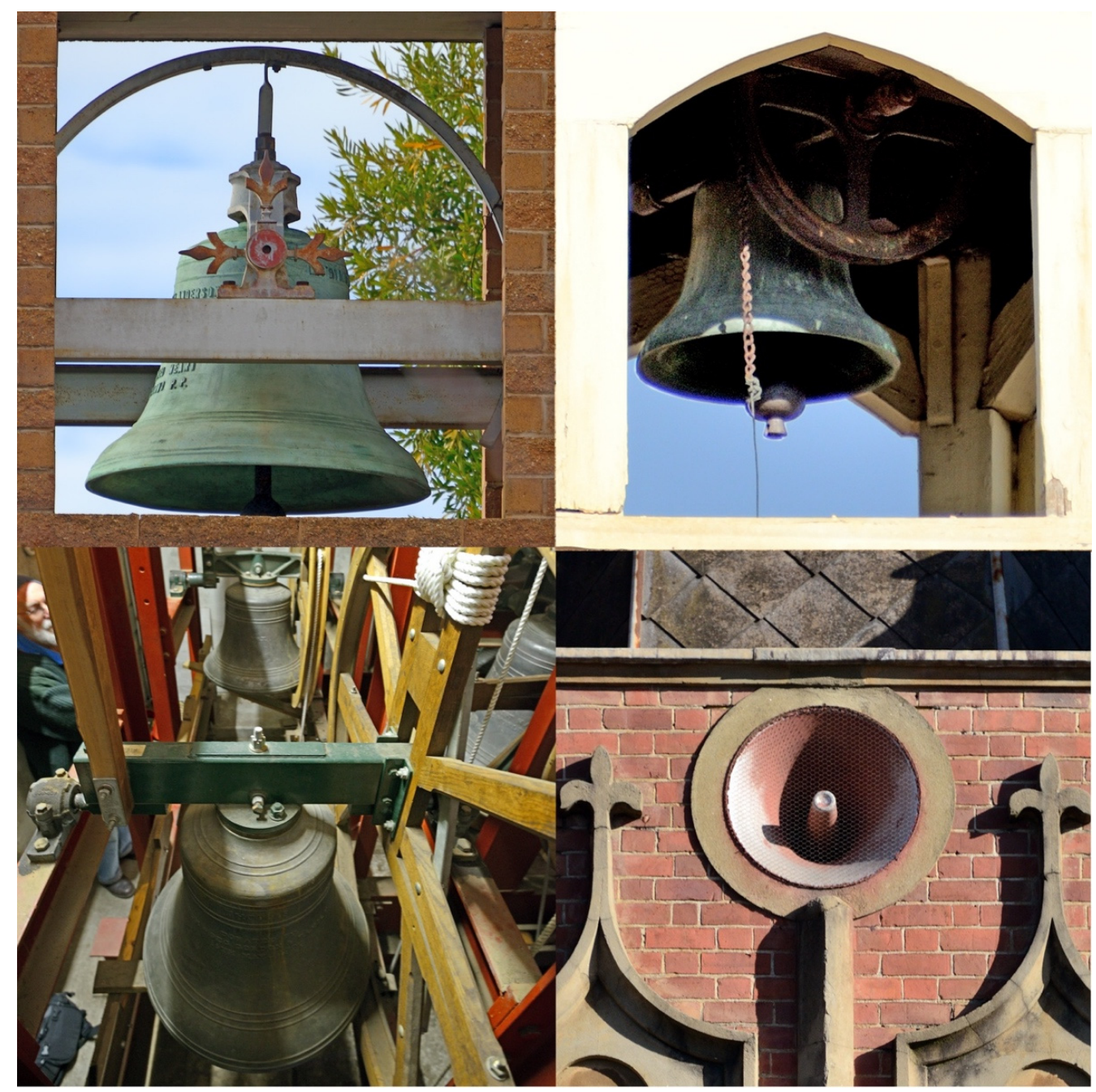

Figure 4. Types of bells used in churches in NSW. Clockwise from top left: main tenor bell, campanile, Sacred Heart Catholic Church; Angelus bell, bell-côte, St. Ursula's Catholic Convent; speaker system, St. David's Uniting (originally Presbyterian) Church; bell arrangement, St Matthew's Anglican Church (all Albury) (photos: Dirk HR Spennemann).

\section{Results}

\subsection{Presence of Bells}

The existence of bells (tower bell, altar/Sanctus bell, sacristy bell, recorded bell or any other bell on the church premises) differed between denominations $(p<0.001)$, with a large proportion of Orthodox (91\%), Catholic (78\%) and Anglican churches (76\%) reporting bells on church premises (Table 2), while a large proportion of Uniting churches reported having no bells (71\%). It is important to note here that churches may have multiple bells on-site, external bells and/or additional internal/liturgical bells.

Table 2. Percentage of NSW churches that have bells on the church premises.

\begin{tabular}{ccccc}
\hline- & Bells & No Bells & Unsure & n \\
\hline Anglican & 76.62 & 21.65 & 1.73 & 231 \\
Catholic & 77.78 & 21.21 & 1.01 & 99 \\
Orthodox & 90.91 & 9.09 & 0.00 & 11 \\
Presbyterian & 46.00 & 54.00 & 0.00 & 50 \\
Uniting & 26.89 & 70.59 & 2.52 & 119 \\
\hline
\end{tabular}


Tower bells were the most common type of external bell reported across all denominations, ranging from $66 \%$ of Uniting churches to $87 \%$ of Presbyterian churches (Table 3 ). The use of a campanile to mount the bells was more prominent among Uniting churches, but significantly so only compared with the Catholic churches $(p<0.01)$. Both Uniting and Presbyterian churches had the highest percentage of recorded bells (analogue or digital recordings) (17.4\% each), followed by Catholic $(9.1 \%)$ and Anglican churches $(4 \%)$. All Orthodox churches to respond indicated they had only acoustic bells on the church premises. Catholic churches had a significantly higher prevalence of having internal/liturgical bells $(63.6 \% ; p<0.01)$ compared with any other denomination, followed by Orthodox and Anglican churches.

Table 3. Bell types used in NSW churches (in \%) by denomination, based on responses that house bells on church premises. Multiple responses (external/internal) possible.

\begin{tabular}{cccccc}
\hline - & \multicolumn{2}{c}{ External Physical Bell } & Recorded Bell & Internal/Liturgical & - \\
\hline- & Tower Bell & Campanile & & & $\mathbf{n}$ \\
\hline Anglican & 81.3 & 8.5 & 4.0 & 19.3 & 176 \\
Catholic & 81.8 & 3.9 & 9.1 & 63.6 & 77 \\
Orthodox & 80.0 & 10.0 & - & 20.0 & 10 \\
Presbyterian & 87.0 & - & 17.4 & - & 23 \\
Uniting & 65.6 & 18.8 & 17.4 & 6.3 & 32 \\
Overall & 79.14 & 8.24 & 9.58 & 21.84 & 318 \\
\hline
\end{tabular}

Both the distribution of the number and proportion of bell towers/campanile varied significantly between churches built in different historical periods $(p<0.001)$. Whilst there is no known comprehensive inventory of the number of churches built in each of these periods in NSW, this survey captures about $40 \%$ of those churches that are still in liturgical service (based on the response rate, see Methodology). The majority of bell towers were reported from churches dating to the 1851-1890 period $(n=94)$, which coincides with the period of agricultural expansion and intensification in regional and rural NSW [40,41], and the post-1945 $(n=63)$ period, which saw substantial immigration, primarily into the metropolitan area (Figure 5).

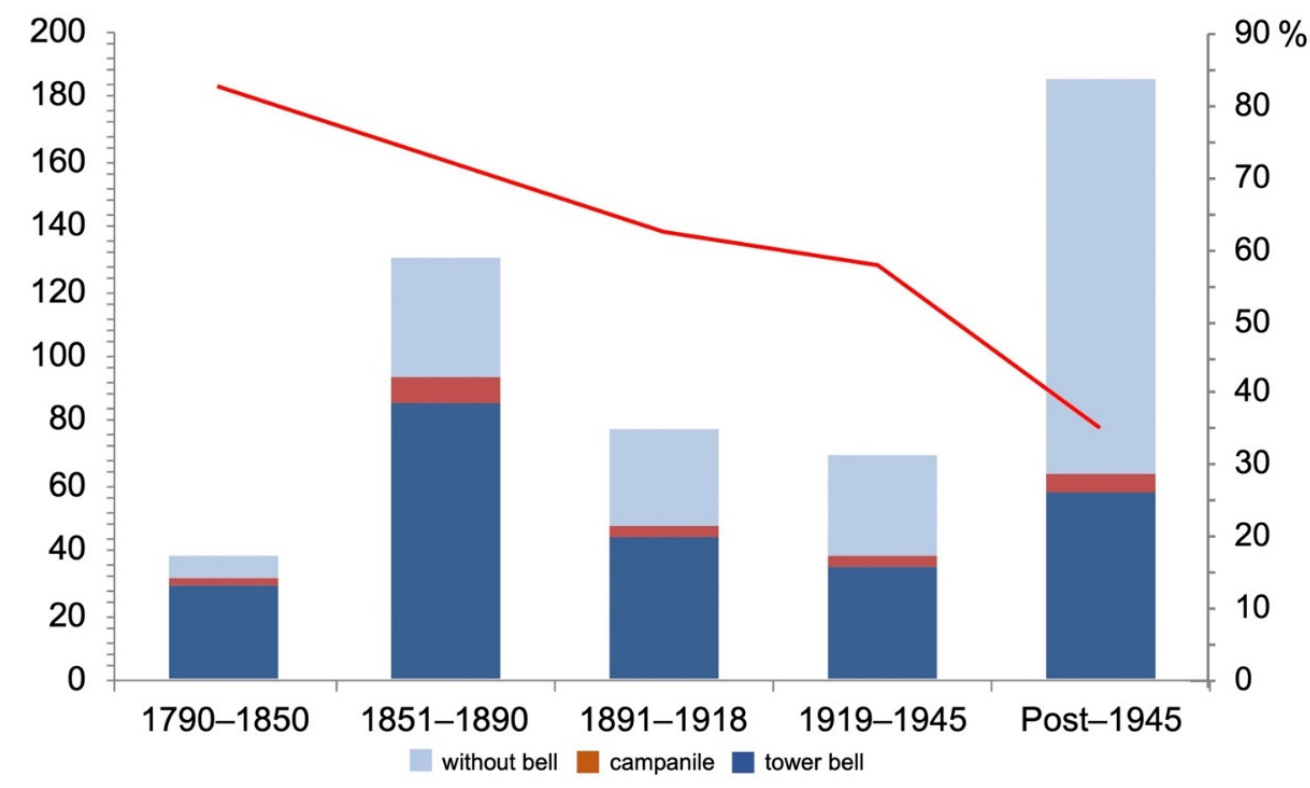

Figure 5. Types of bells in NSW churches per historical period. The line graph shows the proportion of churches containing external bells per period. 
A clear decreasing trend can be observed in the proportion of churches with external bells (Figure 5), from $82 \%$ of churches during the earliest period (1790-1850) to $34 \%$ of churches built in the most recent period (post-1945) $(r=-0.310, p<0.001)$. Taking into account regionality, the steady decline in churches with bells in the major cities (i.e., Greater Sydney) from $85.7 \%$ prior to 1850 to $38.2 \%$ post- 1945 is significant $\left(r^{2}=0.9875\right)$ (Table 4 ). This chronological trend is echoed, albeit slightly less pronounced, among churches in inner regional communities of NSW $\left(r^{2}=0.8165\right)$. Looking at the influence of regionality for the churches built post-1945, a clear trend emerges correlating an increasing proportion of churches with bells with increasing remoteness $\left(r^{2}=0.9156\right)$. This was already a factor during the preceding 1919-1945 period $\left(r^{2}=0.8425\right)$ as well as the period of major expansion of European settlement in NSW $\left(1851-1890, r^{2}=0.8193\right)$. There is a clear regional trend of increasing presence of external church bells from Greater Sydney $(52.6 \%)$ and inner $(62.5 \%)$ and outer regional NSW $(78.6 \%)$ to remote $(75 \%)$ and very remote NSW $(100 \%)$ $\left(r^{2}=0.8942\right)$. If we remove the post- 1945 churches from consideration, however, the trend is much less clear $\left(r^{2}=0.5373\right)$.

Table 4. Proportion of churches that contain bells (all denominations) by period and regionality.

\begin{tabular}{cccccc}
\hline - & $\begin{array}{c}\text { Greater } \\
\text { Sydney }\end{array}$ & $\begin{array}{c}\text { Inner } \\
\text { Regional } \\
\text { NSW }\end{array}$ & $\begin{array}{c}\text { Outer } \\
\text { Regional } \\
\text { NSW }\end{array}$ & $\begin{array}{c}\text { Remote } \\
\text { NSW }\end{array}$ & $\begin{array}{c}\text { Very Remote } \\
\text { NSW }\end{array}$ \\
\hline $1790-1850$ & 85.71 & 100 & 87.50 & - & - \\
$1851-1890$ & 73.91 & 67.86 & 84.00 & 100 & 100 \\
$1891-1918$ & 59.26 & 76.47 & 84.00 & 60.00 & 100 \\
$1919-1945$ & 44.83 & 63.64 & 80.00 & 71.43 & 100 \\
Post-1945 & 38.18 & 41.67 & 68.75 & 100 & 100 \\
\hline
\end{tabular}

Setting aside Orthodox churches due to the small sample size, the proportions of churches with bells over time and broken down by denomination (Table 5) show a decline among all denominations. The trend of decreasing proportions is near linear and significant for Anglican churches $\left(r^{2}=0.8749\right)$ but much less so for Presbyterian $\left(r^{2}=0.7715\right)$ and Uniting churches $\left(r^{2}=0.6673\right)$. For the Catholic churches, the trend correlation is strong only once the early period $(1790-1850)$ is omitted $\left(r^{2}=0.9043\right)$.

Table 5. Proportion of churches that contain bells by period and denomination.

\begin{tabular}{ccccccc}
\hline - & Anglican & Catholic & Orthodox & Presbyterian & Uniting & Total \\
\hline $1790-1850$ & 96.00 & 60.00 & 100.00 & 100.00 & 75.00 & 89.47 \\
$1851-1890$ & 92.42 & 90.00 & - & 66.67 & 32.00 & 76.98 \\
$1891-1918$ & 86.49 & 88.89 & 100.00 & 33.33 & 41.67 & 72.50 \\
$1919-1945$ & 76.92 & 80.00 & - & 50.00 & 39.13 & 62.86 \\
Post-1945 & 53.95 & 68.42 & 87.50 & 26.67 & 14.58 & 45.95 \\
\hline
\end{tabular}

The overall reduction in post-1945 churches with bells, as compared with a baseline comprising the entire century before 1890, is most pronounced among the Presbyterian (37.8\% of 1890 values) and Uniting churches (38.5\% of 1890 values), while it is least expressed among the Catholic churches ( $81.5 \%$ of 1890 values).

\subsection{Number, Size and Origin of the Bells}

While the majority (83.2\%) of all churches with external bells (independent of denomination) had only a single tower bell on the church premises, some churches had up to twenty bells (Table 6). Setting aside the small number of Orthodox churches, Anglican churches have far more instances of churches $(22.5 \%)$ with multiple bells than Catholic churches $(17 \%)$ and the other denominations (10\%, setting aside Orthodox churches). Sixteen of the churches reported exactly eight tower bells on-site, correlating with the eight notes of a musical octave (Table 6). All but one of these, a pre-1890 Uniting church near 
Richmond which had its bells installed in 1999, belong to Anglican congregations in Greater Sydney (8), inner regional NSW (3) and outer regional NSW (4). Free-form comments to the survey stated that many churches with multiple bells undertook change ringing, where melodic patterns and permutations are played from (or from parts of) a diatonic musical scale. There is a clear and significant trend of a decrease in churches with multiple external bells from the Greater Sydney area (29.6\%) to inner regional NSW (20.8\%), outer regional NSW (14.6\%) and remote and very remote NSW (both $0 \%)\left(r^{2}=0.9454\right)$.

Table 6. Number of external bells at each NSW church reporting bell use.

\begin{tabular}{cccccccccccccc}
\hline - & \multicolumn{10}{c}{ Number of Bells per Church } \\
\hline Denomination & 1 & 2 & 3 & 5 & 6 & 7 & 8 & 9 & 10 & 13 & 14 & 20 \\
Anglican & 107 & - & 2 & 1 & 5 & & 15 & - & 2 & 4 & 1 & 1 \\
Catholic & 44 & 2 & 2 & - & 1 & 1 & - & 2 & - & - & 1 & - \\
Orthodox & 6 & 1 & 1 & 1 & - & - & - & - & - & - & - & - \\
Presbyterian & 18 & 2 & - & - & - & - & - & - & - & - & - & - \\
Uniting & 18 & - & - & - & 1 & - & 1 & - & - & - & - & - \\
All denominations & 193 & 5 & 5 & 2 & 7 & 1 & 16 & 2 & 2 & 4 & 2 & 1 \\
\hline
\end{tabular}

Two thirds $(67.5 \%)$ of the bells fall below a 24 -inch diameter. A trend of proportions of churches with bells larger than a 24-inch diameter can be observed from Greater Sydney $(29.6 \%)$ to $50 \%$ in very remote NSW, but the correlation is weak $\left(r^{2}=0.6939\right)$.

Most bells were commissioned for the specific church, or the church's predecessor building at the same location, and were cast on-site, in Sydney or, more commonly, were imported from foundries in Ireland and especially England, primarily John Taylor \& Co (Loughborough) and Whitechapel Bell Foundry (London), but also Warner Bros (London). A small number of bells reportedly had a more varied origin as they were appropriated from historical buildings such as the fire station or school (2), from ships (2) and repurposed, or were acquired from decommissioned churches in Australia and England.

\subsection{Ringing the Bells}

The traditional common assumption among the general public is that church bells are being rung, if not as a regular call to service, then at least on special occasions. The expression 'wedding bells' has become synonymous with the event. From the perspective of aural heritage, it is important to determine to what extent church bells are actually used. The survey asked participants about the nature of bell ringing on church grounds, with questions referring to whether installed bells were actively rung, and if so, how frequently and on what occasions they were rung (i.e., weddings, baptisms, funerals, regular services, major events and bell ringing practice). A moderate percentage of respondents from Uniting, Catholic and Anglican churches did not answer the question about whether any tower bells on-site were actually rung (22\%, 20\% and $11 \%$ respectively), suggesting that in these instances bell ringing is uncommon and not memorable.

The proportion of churches that currently ring external bells clearly differs across the regionality category $(p<0.001)$. For some time periods, there is a clear trend of greater tower bell use across the trajectory from Greater Sydney to regional to remote NSW (1919-1945, $r^{2}=0.8017$; post-1945, $r^{2}=0.9417$ ) (Table 7). Likewise, there is a trend in Greater Sydney, where older churches are more likely to ring their bells than post-1945 churches $\left(r^{2}=0.9884\right)$. This trend is not significant for churches in inner regional $\left(r^{2}=0.6174\right)$ and outer regional NSW $\left(r^{2}=0.2870\right)$. The proportions of churches with external bells that actually ring them show no regional $\left(r^{2}=0.3873\right)$ or chronological trends (Greater Sydney, $r^{2}=0.2361$; inner regional, $r^{2}=0.3194$; outer regional, $\left.r^{2}=0.0132\right)$. 
Table 7. Proportions of churches ringing bells (for each individual period and regionality).

\begin{tabular}{cccccc}
\hline - & $\begin{array}{c}\text { Greater } \\
\text { Sydney }\end{array}$ & $\begin{array}{c}\text { Inner } \\
\text { Regional } \\
\text { NSW }\end{array}$ & $\begin{array}{c}\text { Outer } \\
\text { Regional } \\
\text { NSW }\end{array}$ & $\begin{array}{c}\text { Remote } \\
\text { NSW }\end{array}$ & $\begin{array}{c}\text { Very Remote } \\
\text { NSW }\end{array}$ \\
\hline $1790-1850$ & 76.47 & 88.89 & 71.43 & - & - \\
$1851-1890$ & 61.36 & 50.00 & 72.92 & 100.00 & 100.00 \\
$1891-1918$ & 45.83 & 56.25 & 76.19 & 33.33 & 50.00 \\
$1919-1945$ & 38.46 & 63.64 & 76.47 & 66.67 & 100.00 \\
Post-1945 & 20.62 & 22.58 & 53.57 & 66.67 & 100.00 \\
\hline
\end{tabular}

There is no chronological difference in churches with bells installed actually ringing their bells among Anglican $\left(r^{2}=0.4261\right)$ or Catholic congregations $\left(r^{2}=0.2368\right)$. No differences are observable when comparing denominations with each other, with the exception of Presbyterian churches, which use their existing bells significantly less than other churches (Fisher's exact, Anglican $p=0.0111$; Catholic $p=0.0008$; Uniting $p=0.0345$ ). There are no obvious patterns when considering actual denominational use of installed external bells against the regionality of church location.

With reference to the actual mode of ringing tower bells, the majority of the bells rung can be operated manually $(88.8 \%)$, with rope being the primary method to ring the bells $(76.3 \%$; Table 8$)$. Of the recorded/electronic systems installed $(n=27)$ not all are actually used $(\mathrm{n}=21)$, and the use of recorded bells is more common among Catholic and in particular among Presbyterian churches (Table 9). Such bells are not used in remote and very remote Australia, but are more common in the Greater Sydney area (Table 9). The occasions when bells are being rung can be grouped into communal services, lifecycle events and bell training (Table 10). Communal services include regular church services-routine weekly or daily services and masses; and major services—significant events in the Christian calendar such as Easter, Pentecost or Christmas Day. Significant differences between denominations could be observed for bell ringing at major events of the liturgical calendar $(p=0.001)$ and funerals $(p=0.007)$ with Presbyterian churches the least involved. Orthodox and Anglican churches have a higher representation of bell use across the majority of ringing activities compared with the other denominations. Bells were rung primarily for Regular Services across all denominations, ranging from $75 \%$ among Catholic churches to $100 \%$ among Presbyterian churches. Intriguingly, bells were less frequently rung specifically for major events. Among the three life-cycle events (baptism, wedding, funeral), weddings saw by far the greatest frequency of bell use, ranging from almost 75\% among Anglican churches to just over 50\% among Uniting churches (Table 10). Bell ringing on the occasion of a funeral is important for Anglican, Catholic and Orthodox churches (46-75\%), but less so for Uniting and in particular for Presbyterian churches (14-26\%). Baptisms are events with the least frequency of bell ringing, almost on par with bells being rung for bell training (Table 10).

Table 8. Distribution of bell ringing operating systems, all denominations.

\begin{tabular}{ccc}
\hline Bell Ringing Mechanism Type & $\mathbf{n}$ & $\mathbf{\%}$ \\
\hline Manual-rope & 184 & 76.3 \\
Manual-rope and electronic & 4 & 1.6 \\
Manual-unspecified & 26 & 10.8 \\
All manual & 214 & 88.8 \\
Electronic-manual & 12 & 5.0 \\
Electronic-programmed & 7 & 2.9 \\
Electronic-manual and programmed & 8 & 3.3 \\
All Electronic & 27 & 11.2 \\
\hline
\end{tabular}


Table 9. Use of recorded bells (in \%).

\begin{tabular}{cccc}
\hline By Denomination & \multicolumn{2}{c}{ By Regionality } \\
\hline Anglican & 4.42 & Greater Sydney & 10.57 \\
Catholic & 9.09 & Inner Regional & 3.08 \\
Orthodox & - & Outer Regional & 5.45 \\
Presbyterian & 17.39 & Remote & - \\
Uniting & 6.25 & Very Remote & - \\
$\mathrm{n}$ & 323 & $\mathrm{n}$ & 323 \\
\hline
\end{tabular}

Table 10. Percentage of external bell ringing activity use across each denomination in NSW churches, for those who identified as ringing external bells on church premises (Chi-square: differences between denominations for each activity).

\begin{tabular}{|c|c|c|c|c|c|c|}
\hline \multirow{2}{*}{$\begin{array}{l}- \\
-\end{array}$} & \multicolumn{2}{|c|}{ Communal Services } & \multicolumn{3}{|c|}{ Life-Cycle Events } & \multirow{2}{*}{$\begin{array}{c}- \\
\text { Bell } \\
\text { Training } \\
(p=0.064)\end{array}$} \\
\hline & $\begin{array}{c}\text { Regular } \\
\text { Services } \\
(p=0.090)\end{array}$ & $\begin{array}{c}\text { Major } \\
\text { Events } \\
(p=0.001)\end{array}$ & $\begin{array}{c}\text { Baptisms } \\
(p=0.305)\end{array}$ & $\begin{array}{l}\text { Weddings } \\
(p=0.082)\end{array}$ & $\begin{array}{c}\text { Funerals } \\
(p=0.007)\end{array}$ & \\
\hline Anglican & 87.79 & 57.25 & 19.08 & 74.81 & 46.56 & 22.90 \\
\hline Catholic & 75.00 & 59.62 & 7.69 & 61.54 & 51.92 & 9.62 \\
\hline Orthodox & 87.50 & 87.50 & 12.50 & 62.50 & 75.00 & 12.50 \\
\hline Presbyterian & 100.00 & 14.29 & 7.14 & 64.29 & 14.29 & 0.00 \\
\hline Uniting & 82.61 & 34.78 & 13.04 & 52.17 & 26.09 & 8.70 \\
\hline
\end{tabular}

While not statistically significant, there were differences for specific bell ringing activities across each regionality, with visual trends suggesting that tower bells were rung more in Greater Sydney and inner regional NSW compared with remote and very remote NSW for weddings $\left(r^{2}=0.8664\right)$, major liturgical events $\left(r^{2}=0.8603\right)$ and bell training $\left(r^{2}=0.9016\right)$ (Table 11).

Table 11. Percentage of tower and campanile specific bell ringing activity use of NSW churches across each Remoteness Index, for those who identified as ringing tower bells on church premises.

\begin{tabular}{ccccccc}
\hline - & $\begin{array}{c}\text { Regular } \\
\text { Services } \\
(p=\mathbf{0 . 2 9 7})\end{array}$ & $\begin{array}{c}\text { Major } \\
\text { Events } \\
(p=\mathbf{0 . 5 8 6})\end{array}$ & $\begin{array}{c}\text { Baptisms } \\
(p=\mathbf{0 . 0 1 5})\end{array}$ & $\begin{array}{c}\text { Weddings } \\
(p=\mathbf{0 . 2 4 6})\end{array}$ & $\begin{array}{c}\text { Funerals } \\
(\boldsymbol{p}=\mathbf{0 . 1 8 8})\end{array}$ & $\begin{array}{c}\text { Bell } \\
\text { Training } \\
(\boldsymbol{p}=\mathbf{0 . 2 3 9})\end{array}$ \\
\hline $\begin{array}{c}\text { Greater } \\
\text { Sydney }\end{array}$ & 83.95 & 60.49 & 8.64 & 75.31 & 24.69 & 23.46 \\
$\begin{array}{c}\text { Inner } \\
\text { Regional } \\
\quad \text { Outer } \\
\text { Regional } \\
\text { Remote } \\
\text { Very }\end{array}$ & 88.64 & 56.82 & 15.91 & 75.00 & 93.18 & 18.18 \\
Remote & 75.24 & 50.59 & 15.29 & 61.18 & 36.47 & 11.76 \\
\hline
\end{tabular}

\subsection{Changes in Bell Ringing Frequency}

There are no known historical data on bell ringing frequency at any scale in NSW. This information is important to determine not only the current or past frequencies of bell ringing practices, but to calculate any change in bell ringing frequencies over time as this may reflect changes in societal attitudes. Moreover, any temporal trends may influence the future management of sound heritage.

Therefore, survey questions sought information on the approximate frequency of installed bells being rung for official or celebratory occasions over three decadal periods (1990s, 2000s, 2010s). These were chosen as combined, they comprise a human generation, 
and the reported perceptions of changes should fall well within the recent human workinglife memory of the respondents.

The majority of churches across all denominations reported no bell ringing frequency change for each past decadal period (Table 12). During the 1990s to 2000s, negative and positive changes in bell ringing frequency almost cancel each other out with the exception of Presbyterian churches, who reduced or terminated the ringing in one third of their churches (setting aside the small Orthodox sample). In the past decade, Presbyterian churches reduced the ringing in another eighth of their churches, while one third of Uniting churches were likewise affected. Compared with that, the bell ringing frequency among Catholic churches increased by $10 \%$ in the past decade (Table 12).

Table 12. Changes in bell ringing practices for each denomination of NSW churches, 1990s to 2010s: proportion of churches.

\begin{tabular}{ccccccc}
\hline Change Period & Change & Anglican & Catholic & Orthodox & Presbyterian & Uniting \\
\hline 1990s vs. 2000s & Decrease & 12.5 & 6.9 & 0.0 & 33.3 & 16.7 \\
- & No change & 78.1 & 86.2 & 75.0 & 66.7 & 66.7 \\
- & Increase & 9.4 & 6.9 & 25.0 & 0.0 & 16.7 \\
2000s vs. 2010s & Decrease & 12.5 & 0.0 & 0.0 & 16.7 & 33.3 \\
- & No change & 81.3 & 89.7 & 75.0 & 83.3 & 66.7 \\
- & Increase & 6.3 & 10.3 & 25.0 & 0.0 & 0.0 \\
1990s vs. 2010s & Decrease & 15.1 & 3.7 & 0.0 & 25.0 & 33.3 \\
- & No change & 71.7 & 81.5 & 50.0 & 75.0 & 66.7 \\
- & Increase & 13.2 & 14.8 & 50.0 & 0.0 & 0.0 \\
\hline
\end{tabular}

As actual positive or negative changes at a church level may not determine the amount of bell ringing frequency change as perceived by the communities, the responses were converted to approximate days (see Methodology) and a net change calculated (Table 13). While there is much variability, the overall net change over the past 20-year period shows an increase in bell ringing days for Uniting and especially Catholic churches, minimal change among Anglican churches and a considerable loss among Presbyterian churches (Table 13).

Table 13. Changes in bell ringing practices for each denomination of NSW churches, 1990s to 2010s: net change in terms of the proportion of bells and the difference in days rung.

\begin{tabular}{ccccccc}
\hline Change Period & Change & Anglican & Catholic & Orthodox & Presbyterian & Uniting \\
\hline 1990s vs. 2000s & proportion & -3.1 & 0 & 25 & -33.3 & 0 \\
- & ringing days & 1.68 & 1.90 & 8.25 & 0.00 & -3.03 \\
2000 s vs. 2010s & proportion & -6.2 & 10.3 & 25 & -16.7 & -33.3 \\
- & ringing days & -0.72 & 18.67 & 0.33 & -13.21 & 6.45 \\
1990 s vs. 2010s & proportion & -1.9 & 11.1 & 50 & -25 & -33.3 \\
- & ringing days & -0.08 & 23.22 & 8.63 & -12.04 & 5.78 \\
\hline
\end{tabular}

When we consider this change on a regional basis by denomination, differences are evident (Table 14). Anglican churches ring their bells more frequently in Greater Sydney and remote NSW, with reduced activity in both inner and outer regional NSW communities, while Catholic churches see a dramatic increase across all regionalities except very remote regions, where there has been a large decrease. Presbyterian churches see a net loss particularly in Greater Sydney and inner regional NSW, as well as in outer regional NSW, with Uniting churches showing a loss in this region also. 
Table 14. Changes in bell ringing practices for each denomination of NSW churches by regionality, 1990s to 2010s. Blank cells indicate no data.

\begin{tabular}{cccccc}
\hline- & $\begin{array}{c}\text { Greater } \\
\text { Sydney }\end{array}$ & $\begin{array}{c}\text { Inner } \\
\text { Regional } \\
\text { NSW }\end{array}$ & $\begin{array}{c}\text { Outer } \\
\text { Regional } \\
\text { NSW }\end{array}$ & $\begin{array}{c}\text { Remote } \\
\text { NSW }\end{array}$ & $\begin{array}{c}\text { Very Remote } \\
\text { NSW }\end{array}$ \\
\hline \multicolumn{7}{c}{ Change in net ringing days (average) } \\
\hline Anglican & 2.32 & -2.86 & -2.51 & 13.00 & 1.38 \\
Catholic & 32.50 & 17.94 & 21.70 & 52.00 & -46.00 \\
Orthodox & 8.63 & - & - & - & - \\
Presbyterian & -26.00 & -13.00 & -8.10 & 0.00 & - \\
Uniting & 0.00 & 22.64 & -6.81 & - & - \\
\hline \multicolumn{7}{c}{ Proportion of churches with changes } \\
Catholic & 9.80 & 0.00 & -5.10 & 25.00 & 25.00 \\
Orthodox & 38.00 & 33.33 & 40.00 & 0.00 & - \\
Presbyterian & -58.00 & - & - & - & - \\
Uniting & 0.00 & -25.00 & 0.00 & 0.00 & - \\
\hline
\end{tabular}

\section{Discussion}

The presence of external bells in churches in NSW and their use are an expression of the liturgical and communal priorities of the congregations. The broad scope of the present study, which undertakes a supra-regional investigation into church bell ringing, finds that bell statistics and ringing practices are non-uniform across the state of NSW with reference to both church denomination and regionality. While hand bells and internal bells are a liturgically significant component of some churches, and external bells have been shown to be a quotidian symbol for the community and focus point for sacred tenets [42], it would appear that external bells in NSW are sometimes seen as a non-essential 'luxury item' that could be foregone in cases where the finances of the congregation were insufficient. This can be demonstrated by the large number of country churches without bell towers, even though they had been foreshadowed in the original plans. Today, many of these churches still lack towers in their entirety, or exhibit tower bases with the ornamental portions either completed below ridge height of the nave or executed as weatherboard structures. This wealth differential seems to be more pronounced in outer regional NSW as well as in remote and very remote NSW. In this bell study, the wealth differential also finds an expression in the proportion of churches with multiple external bells in the Greater Sydney area $(29.6 \%)$, outer regional NSW (14.6\%) and remote and very remote NSW (both $0 \%$ ) $\left(r^{2}=0.9454\right)$.

Sociocultural factors also play a role in the use of recorded bells, which are not rung in remote and very remote NSW, but are quite common in the Greater Sydney area $(10.6 \%)$ (Table 9). Congregations in remote and very remote NSW are quite small and thus do not have large capital to invest in non-essential technologies. Moreover, many of the smaller churches in the remote areas are serviced by clergy travelling on a circuit and may only be used for services once every three or four weeks, thereby not warranting such an investment.

While congregational wealth can explain the presence of bells during the nineteenth and early twentieth century, different patterns emerge after World War II. Even though there are some denominational differences, the survey has shown that the presence of external bells decreased over time, with only one third of churches built in the post- 1945 period having bells. There was a clear regional trend of a decreasing presence of external church bells from remote and very remote NSW, where most new churches had bells, to Greater Sydney, where only half the churches had bells. As this trend runs counter to the trend of congregational wealth, sociocultural factors must also be at work, such as awareness of sound projection to residential neighborhoods, changing attitudes towards bells as integral parts of churches and so forth. Furthermore, the results of this survey reflect only those 
churches who responded to the survey and may be reflective of the importance placed on bell ringing by these churches.

The difference in bell ringing availability and practices in NSW is notable between the different denominations. Bells were highly present in churches of the Orthodox, Catholic and Anglican faiths, and Anglican churches were well represented in having a higher proportion of a greater number of bells. These faiths were also well represented in the ringing of bells for weddings, funerals and major events. Such differences can be well explained in the theological traditions of these denominations. In the Orthodox faith, bell ringing has deep religious symbolism whereby the ringing of a bell is not only calling the faithful to prayer, but rather an actual embodiment of the voice of God, with powerful connotations for ringing during sacred events $[43,44]$. Furthermore, the bell activity of Eastern Orthodox churches is dictated in the Typikon for Church Ringing, where specific ringing patterns are called for, each having a unique sound. The patterns include: blagovest (the annunciation), whereby one of the largest bells is struck by three slow strokes with long pauses between, before continuing with more frequent, measured strokes; perebor (funeral tolling), with slow, single peals on each individual bell from the smallest to the largest, ending in a peal of all bells at once; perezvon, a sorrowful but triumphal peal using either single or several strokes on each bell but ringing from the largest to the smallest to symbolize the "self-emptying of our Lord Jesus Christ for our salvation"; and trezvon (triple peal), which utilizes all three kinds of bells, as an expression of Christian joy and triumph [44]. These directives help to explain the remarkably high representation of bells present in the Orthodox churches and the manner of their use. Both Catholic and Anglican churches have an active historical doctrine stipulating the use of bells in church services, with the ringing of Catholic Sanctus bells (small handheld set of bells, which create a joyful sound) being directed by Canon Law [45] and regulated through the Breviarium Romanum and the Missale Romanum [46,47], and the requirement of bells to be tolled before Anglican church services as stipulated by the 1662 Book of Common Prayer [48]. The prevalence of bell ringing in churches of both of these faiths can further be explained by the multitude of bellringing teams or bands, which actively undertake change bell pealing across 33 churches in NSW alone, the vast majority being undertaken in Anglican and Catholic churches [49]. In this activity, bellringers work together to form progressive melodic patterns (methods) using the diatonic scale, with some patterns taking several hours to complete, creating a celebratory peal that could easily be ascribed as the sound of traditional weddings [50]. Whilst there is no overarching directive pertaining to bell ringing in either the Presbyterian or Uniting Church faiths [51,52], the high representation of bell ringing in regular services in an otherwise overall poorly represented number of churches who actually have bells is somewhat surprising, and further research could be undertaken to investigate this.

It is interesting to note that across many denominations, the activity of bell ringing is directed by higher levels of authority. However, emanated sound could also be considered a 'public' resource as any individual within the aural realm is affected by the act of ringing bells. This raises discussion of the notion of auditory identity and issue of ownership of these sounds, reflecting similar issues experienced in previous centuries [42]. Here, in nineteenth century France, there were many examples of conflict over bell ringing occasions, times and periods, between groups including the community, church authorities, local authorities and the clergy themselves. Many contemporary questions still arise pertaining to bell control, religious freedom, ownership of public sounds and decisionmaking, which may involve bells that are either predominantly rung in a functional manner (denominationally directed) or rung as an expression of artistry, joy and for social reasons (change ringing). The questions of auditory identity or ownership of sounds are further complicated when there is either an increase or reduction in bell ringing activity, some of which this study has exposed.

The change in bell ringing frequency is particularly curious-a reduction in ringing could easily be correlated with issues such as secularization and religious change in modern 
times [53,54], but the increase in bell ringing frequency among Catholic churches and the increase in bell ringing hours for Anglican and Catholic churches runs counter to this trend; the number of church-attending Catholics in Australia reduced by a third between 1996 and 2016 (around 12,000 people a year) [55] whereas both the proportion and actual number of bell ringing hours increased over a similar period in NSW Catholic churches. The reasons are again unclear, but possible examples include the increase in bell peal ringing teams in these churches, or the use of the bell as an advertisement to attract parishioners to attempt to counteract congregational decline. The changing role of bells in worship, ritual and/or community life presents interesting questions about the persistence of sacred endeavors actually presenting themselves in the public sphere.

Particularly depressing is the decline in church bell ringing in regional areas-inner and outer regional Anglican, outer regional Uniting, very remote Catholic, and Presbyterian churches across most regionalities. Whilst this paper does not report on degrees of value placed on this activity by either the church or local community, the authors have published such quantitative results of citizen-attributed values in this study elsewhere [36]. These previously reported data show trends whereby the majority of respondents place a higher value on church bell ringing as a form of heritage in comparison to values associated with church services and/or denomination, with this significance increasing considerably towards regional areas. With this in mind, such a decline in church bell ringing in regional areas of NSW warrants further attention and research, particularly from a heritage management perspective.

The survey found that a large number of Uniting churches do not possess external bells, in particular of the post-1945 era. When interpreting these data, it is important to note that most churches belonging to the Uniting Church in Australia are legacy buildings erected prior to 1977 when most congregations of the Methodist Church, about two thirds of the Presbyterian Church and almost all the churches of the Congregational Union of Australia merged to form the Uniting Church. As it is not possible to disaggregate the Uniting Church responses into their prior constituents, the influence of original denominations on the proportional presence of bells cannot be ascertained.

The base assumption of most citizens is that the church bells they hear are physical tower- or campanile-mounted bells that are either manually or mechanically activated and physically rung. The advent of loud speaker technology in the 1950s and 1960s, however, meant that some churches could move from acoustic bells that had to be physically rung, to recorded bells played from analogue records (Figure 6) [56] and later digital recordings. As noted, both Uniting and Presbyterian churches had the highest percentage of recorded bell sounds, followed by Catholic and Anglican churches. All Orthodox churches to respond indicated they had only acoustic bells on the church premises with no reports of any recorded bell or bells. A number of churches use both technologies, playing recordings for the 'common' events, and 'proper' acoustic bells for major events on the liturgical calendar as well as weddings.

The situation is somewhat fluid, however, with some congregations reducing their bell ringing and others increasing or revitalizing it. In most cases where the physical bells are no longer used, they tend to remain in the tower and thus can be reactivated if or once the attitude towards their use changes. This has indeed occurred in several instances, while in others bells were installed for the first time during the past ten years. By and large however, the future of bell ringing is less than certain, in particular in regional centers. 


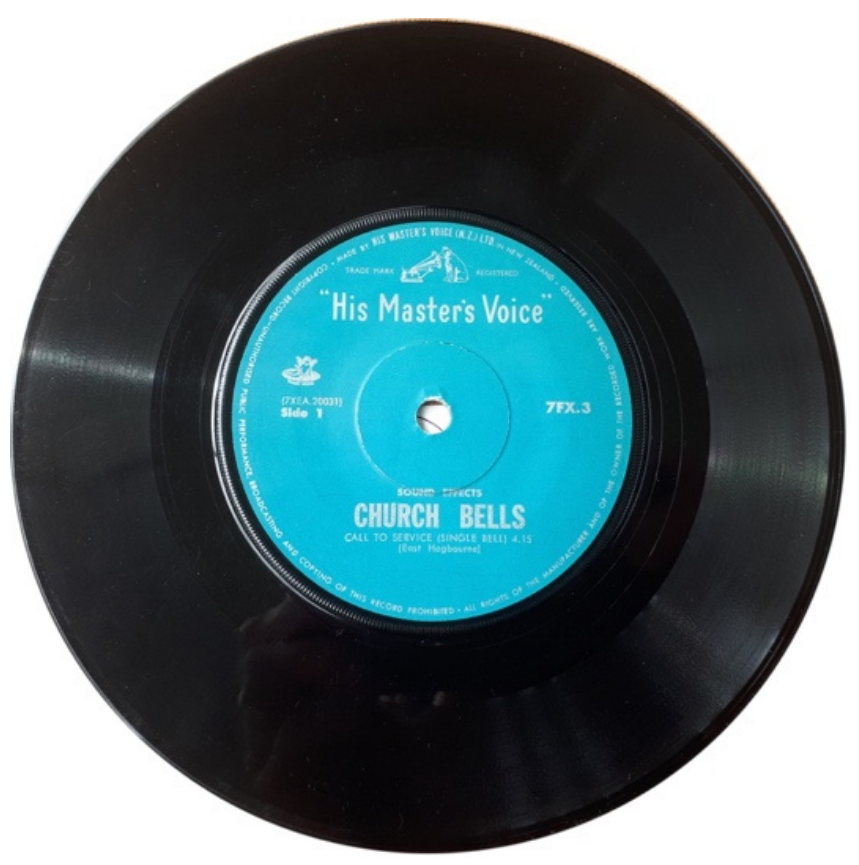

Figure 6. Vinyl $7^{\prime \prime}$ recording of church bell sounds generated by two churches in Berkshire (UK) distributed by the Gramophone Co. Ltd., in Australia and New Zealand (photo: M Parker 2018) [56].

\section{Implications}

The changes in bell ringing frequency are related to both denominational differences and varying degrees of remoteness, with both an increase and a decrease in ringing frequency having divergent implications concerning the social sphere and the potential for aural heritage. The nature of bell ringing is NSW is clearly not uniform across the state, and values and significances attributed to this activity are equally regionally and denominationally distinctive. We can undoubtably learn from this research about the region's religious heritage and the role that this community sound takes in shaping that heritage.

A trend of an increase in church bell ringing may change the way some sections of society think and feel about 'religious broadcasting', being entirely dependent on the individual's perception of the religion in question. Negative perceptions of bell ringing may generate hostility towards the offending enterprise, resulting in conflict. However, a decline in bell practice may negatively affect the heritage value attributed to it by society. Such information as to response of value and significance placed upon bell ringing by those actually hearing it (in the audio detection sphere) is imperative to fully understand any changing patterns of bell ringing.

A trend of a significant decrease in the frequency of bell change ringing could potentially lead to a loss in the skill of this activity. As the mathematics and computations of change ringing are an art form [57], if this technique were to be lost or discontinued, then the resultant sound would never be able to be created and thus heard in the same way again. This may be particularly relevant to regional Anglican churches, who reported a clear decreasing trend in bell ringing frequency. As the recent COVID-19 pandemic has demonstrated the potential for 'heritage sounds' to be temporarily quietened due to government-imposed public restrictions [58,59], it is apposite to consider formal recording of examples of change ringing to safeguard against any future loss. Examples exist of historic recordings of bells rung on special occasions, such as the ringing of Victory bells following Germany's surrender in WWII [60].

There are heavy implications if more remote churches have a higher proportion of bells and there is a clear downwards trajectory of bell ringing in remote churches. If NSW regional communities place more importance on history, tradition and general heritage, sound heritage may be perceived as being highly important to the community in many 
rural areas of Australia, and more research needs to be done to explore this. This may especially be the case in areas where sounds are at high risk of obsolescence or change, such as through the closure of churches in regional Australia due to a general decline in church attendance [61]. This may lead to a church becoming decommissioned and a re-appropriation of bells to another space or being destroyed for their commodity value. The bells and their sounds here may need to be recorded and documented, lest their sounds be lost forever.

\section{Conclusions}

Christian church bell ringing is still heavily practiced in a contemporary setting, although the extent of the ringing is associated with denominational and locational differences. Orthodox, Catholic and Anglican churches have a higher prevalence of bells on-site-especially churches from the earliest period of church history in Australia, and a higher proportion of multiple bells. These churches have a higher tendency to actively ring their bells in part due to theological traditions, although regionality again has an effect. In areas where there is a clear downwards trajectory of bell ringing, research should be undertaken to investigate the community value of these sounds, and subsequent documentation also if these sounds are deemed to have sufficient heritage value.

Author Contributions: Conceptualization, D.H.R.S. and M.P.; methodology, M.P. and D.H.R.S.; validation, M.P. and D.H.R.S.; formal analysis, M.P. and D.H.R.S.; investigation, M.P.; resources, M.P. and D.H.R.S.; data curation, M.P. and D.H.R.S.; writing-original draft preparation, M.P. and D.H.R.S.; writing-review and editing, M.P. and D.H.R.S.; visualization, M.P. and D.H.R.S.; project administration, M.P. and D.H.R.S. All authors have read and agreed to the published version of the manuscript.

Funding: This research received no external funding.

Institutional Review Board Statement: The survey was approved by Charles Sturt University's Faculty of Science Ethics in Human Research Committee (protocol number 400/2017/32).

Informed Consent Statement: Informed consent was obtained from all subjects involved in the study.

Data Availability Statement: Data are not publicly available.

Acknowledgments: The authors are indebted to the participants of the survey for their time and the data they provided. Gail Fuller (Spatial Area Network, Charles Sturt University) kindly posted and hosted the questionnaire on the Charles Sturt University SurveyMonkey ${ }^{\circledR}$ account. Prue Gonzalez (School of Environmental Sciences, Charles Sturt University) acted as co-supervisor of Murray Parker's Honours thesis and commented on draft chapters. The data were re-analyzed for this paper. Bell master Jim Jeffries (Bethanga) kindly facilitated access to the bells of St. Matthew's Church (Albury).

Conflicts of Interest: The authors declare no conflict of interest.

\section{References}

1. ISO Acoustics—Soundscape. Part 1 Definition and Conceptual Framework; ISO 12913-1:2014(E); International Standards Organization: Geneva, Switzerland, 2014.

2. Australia ICOMOS. The Burra Charter. The Australia ICOMOS Charter for Places of Cultural Significance 2013; Australia ICOMOS Inc. International Council of Monuments and Sites: Burwood, VIC, Australia, 2013.

3. U.S. Department of the Interior. The Secretary of the Interior's Standards for Rehabilitation and Guidelines for Rehabilitating Historic Buildings (36 CFR 67); Technical Preservation Services, National Park Service, U.S. Department of the Interior: Washington, DC, USA, 2011.

4. Convention Concerning the Protection of the World Cultural and Natural Heritage; United Nations Educational, Scientific and Cultural Organization: Stockholm, Sweden, 1972.

5. UNESCO. Basic Texts of the 2003 Convention for the Safeguarding of Intangible Cultural Heritage' for Its Protection and Promotion; UNESCO: Paris, France, 2020.

6. Mallik, A.; Chaudhury, S.; Ghosh, H. Nrityakosha: Preserving the intangible heritage of indian classical dance. J. Comput. Cult. Herit. (JOCCH) 2011, 4, 1-25. [CrossRef]

7. Vecco, M. A definition of cultural heritage: From the tangible to the intangible. J. Cult. Herit. 2010, 11, 321-324. [CrossRef] 
8. Farina, A.; Lattanzi, E.; Malavasi, R.; Pieretti, N.; Piccioli, L. Avian soundscapes and cognitive landscapes: Theory, application and ecological perspectives. Landsc. Ecol. 2011, 26, 1257-1267. [CrossRef]

9. Lankford, E.M. Urban soundscapes as indicators of urban health. Environ. Space Place 2009, 1, 27-50. [CrossRef]

10. Bernat, S. Awareness of noise hazards and the value of soundscapes in Polish National Parks. Arch. Acoust. 2013, $38,479-487$. [CrossRef]

11. Jordan, P. Historic approaches to sonic encounter at the berlin wall memorial. Acoustics 2019, 1, 517-537. [CrossRef]

12. Schafer, R.M. The Soundscape: Our Sonic Environment and the Tuning of the World; Destiny Books: Montpelier, VT, USA, 1994.

13. Larsen, O.N.; Radford, C. Acoustic Conditions Affecting Sound Communication in Air and Underwater. In Effects of Anthropogenic Noise on Animals; Springer: Berlin/Heidelberg, Germany, 2018; pp. 109-144.

14. Dumyahn, S.; Pijanowski, B. Beyond noise mitigation: Managing soundscapes as common-pool resources. Landsc. Ecol. 2011, 26, 1311-1326. [CrossRef]

15. Kang, J.; Aletta, F.; Gjestland, T.T.; Brown, L.A.; Botteldooren, D.; Schulte-Fortkamp, B.; Lercher, P.; van Kamp, I.; Genuit, K.; Fiebig, A.; et al. Ten questions on the soundscapes of the built environment. Build. Environ. 2016, 108, 284-294. [CrossRef]

16. Jang, G.-S.; Kook, C. The selection of introduced sounds to improve the soundscape in the public spaces. J. Physiol. Anthr. Appl. Hum. Sci. 2005, 24, 55-59. [CrossRef]

17. Ansay, S.; Zannin, P.H.T. Evaluation of the Acoustic Environment in a Protestant Church Based on Measurements of Acoustic Descriptors. J. Build. Constr. Plan. Res. 2016, 4, 18. [CrossRef]

18. García, L.; Parra, L.; Gomis, B.P.; Cavallé, L.; Pérez Guillén, V.; Pérez Garrigues, H.; Lloret, J. Valencia's Cathedral church bell acoustics impact on the hearing abilities of bell ringers. Int. J. Environ. Res. Public Health 2019, 16, 1564. [CrossRef]

19. Felipe Silva, L.; Cabral, R. Noise exposure levels of priests and worshippers in protestant churches. Int. J. Occup. Saf. Ergon. 2011, 17, 79-86. [CrossRef]

20. Elicio, L.; Martellotta, F. Acoustics as a cultural heritage: The case of Orthodox churches and of the "Russian church" in Bari. J. Cult. Herit. 2015, 16, 913-918. [CrossRef]

21. Suárez, R.; Alonso, A.; Sendra, J.J. Intangible cultural heritage: The sound of the Romanesque cathedral of Santiago de Compostela. J. Cult. Herit. 2015, 16, 239-243. [CrossRef]

22. Suárez, R.; Alonso, A.; Sendra, J.J. Archaeoacoustics of intangible cultural heritage: The sound of the Maior Ecclesia of Cluny. J. Cult. Herit. 2016, 19, 567-572. [CrossRef]

23. Syamsiyah, N.R.; Dharoko, A.; Utami, S.S. Sound preservation at the Grand Mosque of Yogyakarta in Indonesia: The acoustic performance of the traditional architecture. In Proceedings of the AIP Conference, Surakarta, Indonesia, 13-14 December 2017 ; p. 040032.

24. Diaz, J. Church bells and ground motions. J. Seismol. 2020, 1-10. [CrossRef]

25. Acun, V.; Yilmazer, S.; Taherzadeh, P. Perceived auditory environment in historic spaces of Anatolian Culture: A case study on Haci Bayram mosque. In Proceedings of the 23rd International Congress on Sound and Vibration, Athens, Greece, 10-14 July 2016.

26. Yilmazer, S.; Acun, V. A grounded theory approach to assess indoor soundscape in historic religious spaces of Anatolian culture: A case study on Hacı Bayram Mosque. Build. Acoust. 2018, 25, 137-150. [CrossRef]

27. Jeon, J.Y.; Hwang, H.; Hong, J.Y. Soundscape evaluation in a Catholic cathedral and Buddhist temple precincts through social surveys and soundwalks. J. Acoust. Soc. Am. 2014, 135, 1863-1874. [CrossRef] [PubMed]

28. Hong, J.Y.; Lee, P.J.; Jeon, J.Y. Evaluation of urban soundscape using soundwalking. In Proceedings of the 20th International Congress on Acoustics, Sydney, Australia, 23-27 August 2010.

29. Zhang, D.; Zhang, M.; Liu, D.; Kang, J. Soundscape evaluation in Han Chinese Buddhist temples. Appl. Acoust. 2016, 111, 188-197. [CrossRef]

30. Omlin, S.; Brink, M. Awakening effects of church bell noise: Geographical extrapolation of the results of a polysomnographic field study. Noise Health 2013, 15, 332-341. [CrossRef] [PubMed]

31. Коvас̌ič, М. Official regulations and perceptual aspects of bell ringing. МУЗИКОЛОГИЈА/Musicology 2017, $22,59-73$.

32. Ge, J.; Guo, M.; Yue, M. Soundscape of the west lake scenic area with profound cultural background-A case study of evening bell ringing in Jingci Temple, China. J. Zhejiang Univ. Sci. A 2013, 14, 219-229. [CrossRef]

33. Bickman, L.; Rog, D.J. The Sage Handbook of Applied Social Research Methods; Sage publications: Southend Oaks, CA, USA, 2008.

34. Dillman, D.A.; Smyth, J.D.; Christian, L.M. Internet, Phone, Mail, and Mixed-Mode Surveys: The Tailored Design Method; John Wiley \& Sons, Incorporated: Hoboken, NJ, USA, 2014.

35. Sarantakos, S. Social Research; Macmillan International Higher Education: Basingstoke, UK, 2008.

36. Parker, M.; Spennemann, D.H.R. For whom the bell tolls: Practitioner's views on bell ringing practice in contemporary society in New South Wales (Australia). Religions 2020, 11, 425. [CrossRef]

37. Australian Bureau of Statistics. Census DataR “No Religion” is Rising Fast. 2016. Available online: https://www.abs.gov.au/ AUSSTATS/abs@.nsf/mediareleasesbyReleaseDate/7E65A144540551D7CA258148000E2B85 (accessed on 13 March 2017).

38. Parker, M. The Heritage of Sound in the Built Environment: An Exploration; Charles Sturt University: Albury, NSW, Australia, 2018.

39. Australian Bureau of Statistics. The Australian Statistical Geography Standard (ASGS) Remoteness Structure. Available online: http:/ / www.abs.gov.au/websitedbs/D3310114.nsf/home/remoteness+structure (accessed on 4 April 2017).

40. Robinson, M.E. The New South Wales Wheat Frontier 1851 to 1911; Research School of Pacific Studies, Department of Human Geography, The Australian National University: Canberra, Australia, 1976; Volume HG/10. 
41. Spennemann, D.H.R. Keeping it in the family: Land use and cultural cohesion in the colonial German settlements of Southern New South Wales, 1860-1940. J. R. Aust. Hist. Soc. 2014, 100, 48-68.

42. Corbin, A. Village Bells: Sound and Meaning in the 19th-Century French Countryside; Columbia University Press: New York, NY, USA, 1998.

43. Aldoshina, I.A.; Nicanorov, A. The Investigation of acoustical characteristic of Russian bells. In Proceedings of the Audio Engineering Society Convention 108, Paris, France, 19-22 February 2000.

44. Galperin, M.T.; Burnett, J.E. Typikon for Church Ringing; Editorial Board of the Russian Orthodox Church: Moscow, Russia, 2002.

45. Pope, J.P., II. Codex Iuris Canonici; Vatican: Rome, Italy, 1983.

46. Pope, P., VI. Breviarium Romanum ex Decreto Sacrosancti Concilii Tridentini Restitutum Summorum Pontificum Cura Rcognitum; Vatican: Rome, Italy, 1961.

47. Pope, P., VI. Missale Romanum ex Decreto Sacrosancti Oecumenici Concilii Vaticani II Instauratum; Vatican: Rome, Italy, 1970.

48. Church of England. The Book of Common Prayer, and Administration of the Sacraments, and other Rites and Ceremonies of the Church, According to the Use of the Church of England; Mark Baskett: Oxford, UK, 1762.

49. Australian and New Zealand Association of Bellringers. ANZAB Tower Directory. Available online: https://anzab.org.au/ towers.php?expand=NSWR-NSWS (accessed on 29 June 2021).

50. Australian and New Zealand Association of Bellringers. About Bell Ringing. Available online: https://www.anzab.org.au/about. php (accessed on 3 August 2021).

51. Presbyterian Church of Australia. Worship. The Book of Common Order of the Presbyterian Church of Australia; Presbyterian Church of Australia: Sydney, Australia, 2001.

52. Walton, P. A Short Guide for Daily Prayer; Uniting Church of Australia: Sydney, Australia, 2009.

53. Crockett, A.; Voas, D. Generations of decline: Religious change in 20th-century Britain. J. Sci. Study Relig. 2006, 45, 567-584. [CrossRef]

54. Skirbekk, V.; Kaufmann, E.; Goujon, A. Secularism, fundamentalism, or Catholicism? The religious composition of the United States to 2043. J. Sci. Study Relig. 2010, 49, 293-310. [CrossRef]

55. Martyr, P. It's All in the Numbers; The Catholic Weekly: Sydney, Australia, 12 January 2021.

56. His Master's Voice. Church Bells.7FX.3.Vinyl, 7", 45 RPM. Side A: Call to Service (East Hagbourne); Side B: Call Changes (St. Mary's Church, Thatcham). His Master's Voice (NZ) Limited; Gramophone Co. Ltd.: Wellington, New Zealand, 1968.

57. Johnston, R. A most public of musical performances: The English art of change-ringing. GeoJournal 2006, 65, 17-31. [CrossRef]

58. Parker, M.; Spennemann, D.H.R. Anthropause on audio: The effects of COVID-19 pandemic on church bell ringing in New South Wales (Australia). J. Acoust. Soc. Am. 2020, 148, 1-5. [CrossRef] [PubMed]

59. Spennemann, D.H.R.; Parker, M. Hitting the 'Pause' Button: What does COVID tell us about the future of heritage sounds? Noise Mapp. 2020, 7, 265-275. [CrossRef]

60. His Master's Voice. B.9417-78 r.p.m. Side 1: Bells of (a) Westminster Abbey, (b) York Minster, (c) Coventry Catahdral. Side 2: (a) Bath Abbey; (b) St. Mary's Puddleton. Rung on Victory Day, May 8th, 1945 (Commentator: Frank Phillips) OEA 10480. His Master's Voice; Gramophone Co. Ltd.: London, UK, 1946.

61. Rohde, T.; Smallacombe, A. Rural Church Closures Signal Changes in Religious Practices across Regional Australia; ABC News-West Coast SA: Kimba, Australia, 2018. 